\title{
Investigation of microbial adaptation to salinity variation for treatment of reverse osmosis concentrate by membrane bioreactor
}

Jang, Duksoo; Moon, Chungman; Ahn, Kyuhong; Shin, Hang-Sik; Hwang, Yuhoon

Published in:

Desalination and Water Treatment

Link to article, DOI:

10.1080/19443994.2014.960464

Publication date:

2014

Document Version

Publisher's PDF, also known as Version of record

Link back to DTU Orbit

Citation (APA):

Jang, D., Moon, C., Ahn, K., Shin, H-S., \& Hwang, Y. (2014). Investigation of microbial adaptation to salinity variation for treatment of reverse osmosis concentrate by membrane bioreactor. Desalination and Water Treatment, 1-7. https://doi.org/10.1080/19443994.2014.960464

\section{General rights}

Copyright and moral rights for the publications made accessible in the public portal are retained by the authors and/or other copyright owners and it is a condition of accessing publications that users recognise and abide by the legal requirements associated with these rights.

- Users may download and print one copy of any publication from the public portal for the purpose of private study or research

- You may not further distribute the material or use it for any profit-making activity or commercial gain

- You may freely distribute the URL identifying the publication in the public portal 
This article was downloaded by: [DTU Library]

On: 24 September 2014, At: 02:21

Publisher: Taylor \& Francis

Informa Ltd Registered in England and Wales Registered Number: 1072954 Registered office: Mortimer House, 37-41 Mortimer Street, London W1T 3J H, UK

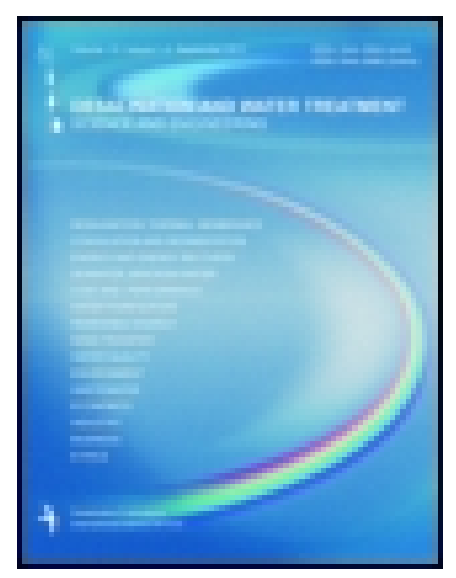

\section{Desalination and Water Treatment}

Publication details, including instructions for authors and subscription information:

http:// www. tandfonline.com/loi/tdwt20

\section{Investigation of microbial adaptation to salinity variation for treatment of reverse osmosis concentrate by membrane bioreactor}

Duksoo J ang ${ }^{a}$, Chungman Moon ${ }^{b}$, Kyuhong Ahn ${ }^{a}$, Hang-Sik Shin $^{b} \&$ Yuhoon Hwang ${ }^{b c}$

a Center for Environmental Technology Research, Korea Institute of Science and Technology, P. O. Box 131, Cheongryang, Seoul 130-650, Republic of Korea

${ }^{b}$ Department of Civil and Environmental Engineering, Korea Advanced Institute of Science and Technology, 291 Daehak-ro, Yuseong-gu, Daejeon 305-701, Republic of Korea

c Department of Environmental Engineering, Technical University of Denmark, Miljøvej, B 113, DK-2800 Kgs. Lyngby, Denmark, Tel. +45 5065 7851; Fax: +45 45932850

Published online: 15 Sep 2014.

To cite this article: Duksoo J ang, Chungman Moon, Kyuhong Ahn, Hang-Sik Shin \& Yuhoon Hwang (2014): Investigation of microbial adaptation to salinity variation for treatment of reverse osmosis concentrate by membrane bioreactor, Desalination and Water Treatment, DOI: 10.1080/ 19443994.2014.960464

To link to this article: http:// dx. doi.org/ 10.1080/ 19443994.2014.960464

\section{PLEASE SCROLL DOWN FOR ARTICLE}

Taylor \& Francis makes every effort to ensure the accuracy of all the information (the "Content") contained in the publications on our platform. However, Taylor \& Francis, our agents, and our licensors make no representations or warranties whatsoever as to the accuracy, completeness, or suitability for any purpose of the Content. Any opinions and views expressed in this publication are the opinions and views of the authors, and are not the views of or endorsed by Taylor \& Francis. The accuracy of the Content should not be relied upon and should be independently verified with primary sources of information. Taylor and Francis shall not be liable for any losses, actions, claims, proceedings, demands, costs, expenses, damages, and other liabilities whatsoever or howsoever caused arising directly or indirectly in connection with, in relation to or arising out of the use of the Content.

This article may be used for research, teaching, and private study purposes. Any substantial or systematic reproduction, redistribution, reselling, loan, sub-licensing, systematic supply, or distribution in any form to anyone is expressly forbidden. Terms \& Conditions of access and use can be found at http:// www.tandfonline.com/page/terms-and-conditions 


\title{
Investigation of microbial adaptation to salinity variation for treatment of reverse osmosis concentrate by membrane bioreactor
}

\author{
Duksoo Jang ${ }^{\mathrm{a}}$, Chungman Moon ${ }^{\mathrm{b}}$, Kyuhong Ahn ${ }^{\mathrm{a}}$, Hang-Sik Shin ${ }^{\mathrm{b}}$, Yuhoon Hwang ${ }^{\mathrm{b}, \mathrm{c}, *}$ \\ ${ }^{a}$ Center for Environmental Technology Research, Korea Institute of Science and Technology, P.O. Box 131, Cheongryang, \\ Seoul 130-650, Republic of Korea \\ ${ }^{b}$ Department of Civil and Environmental Engineering, Korea Advanced Institute of Science and Technology, 291 Daehak-ro, \\ Yuseong-gu, Daejeon 305-701, Republic of Korea \\ ${ }^{c}$ Department of Environmental Engineering, Technical University of Denmark, Miljøvej, B 113, DK-2800 Kgs. Lyngby, Denmark, \\ Tel. +45 5065 7851; Fax: +45 4593 2850; email: yuoh@env.dtu.dk (Y. Hwang)
}

Received 19 March 2014; Accepted 16 August 2014

\begin{abstract}
Even though reverse osmosis (RO) technologies are widely used for sustainable water reclamation, the control of concentrates containing a high concentration of dissolved matters originated from feed water should be considered. The effect of variations in salinity on biological wastewater treatment processes has to be evaluated for combined treatment with RO concentrate in sewage treatment plants. As a preliminary study, the effect of adaptation of seeding sludge on RO concentrate treatment was evaluated. The reactor inoculated by unadapted sludge had a significant inhibition on organic and ammonia removal. Especially, ammonia removal was completely inhibited and removal efficiency was maintained below $20 \%$ during $30 \mathrm{~d}$ of operation. However, the removal efficiencies gradually increased with operation time, and it reached a similar performance to adapted sludge in $40 \mathrm{~d}$ of operation. For a more quantitative study on a microbial adaptation strategy for variations on salt concentration ( $0-20 \mathrm{~g} / \mathrm{L})$, lab-scale membrane bioreactors (7L working volume) with polypropylene hollow fiber membrane module (pore size $0.4 \mu \mathrm{m}$ ) were used with different adaptation strategies: instant and stepwise mode. The performance of the reactor deteriorated with an increasing salt concentration, but it recovered after adaptation periods (30-70 d). Moreover, the inhibition effect of salt could be minimized by a gradual increase in salt concentration. Analysis results for polymerase chain reaction-denaturing gradient gel electrophoresis indicated that nitrifiers were still present in high salinity. These results confirmed that an appropriate adaptation strategy should be determined for $\mathrm{RO}$ concentrate treatment.
\end{abstract}

Keywords: Concentrate treatment; Membrane bioreactor; Microbial adaptation; Salinity

\section{Introduction}

High-pressure membrane processes, e.g. reverse osmosis, have been widely used in water reclamation

*Corresponding author. and desalination, which offers attractive solutions for water scarcity. These processes allow separation of a solution into two streams: permeate, containing the purified water that passes through the membrane, and concentrate, the retained portion that contains dissolved matter originated from feed water such as $\mathrm{Na}^{+}$

1944-3994/1944-3986 ㄷ 2014 Balaban Desalination Publications. All rights reserved. 
and $\mathrm{Cl}^{-}$ions, organics, etc. The nature of such concentrates, therefore, requires options for environmentally friendly management [1].

In recent year, several physical and chemical processes for $\mathrm{RO}$ concentrate management extensively studied include advanced oxidation process, evaporation, and crystallization [2]. However, these processes are generally energy consuming and their operating costs are relatively high. The most common RO concentrate management methods are direct surface water discharge and discharge to a sewage treatment plant [3]. Since RO concentrate contains contaminants from the source water in higher total dissolved solids (TDS) concentrations, the high salinity often causes severe concern about the receiving water. In sewer discharge, the impacts of salinity on the wastewater treatment processes have to be evaluated prior to discharge because the high salinity causes a negative impact on biological wastewater treatment processes [4-6].

To minimize the negative effect of salt, acclimation of microbes on high salinity has been investigated. $\mathrm{Ng}$ et al. [7] were able to treat synthetic wastewater in a sequencing batch reactor (SBR) up to $60 \mathrm{~g} \mathrm{NaCl} / \mathrm{L}$ using acclimated biomass. Yogalakshmi and Joseph [8] also studied the effect of $\mathrm{NaCl}$ shock load in a membrane bioreactor (MBR), and MBR regained its stability after certain recovery periods. Even though the introduced halophilic bacteria are one of the best approaches to increasing the reactor performance in saline conditions [9], sometimes it is difficult to use it for full-scale application. Therefore, it is important to develop an adequate adaptation strategy for saline wastewater treatment in place.

Prior to applying $\mathrm{RO}$ concentrate to a wastewater treatment plant (WWTP), the possibility of microbial acclimation on the saline condition should be evaluated. We evaluated the possibility of microbial acclimation and suggest a suitable adaptation strategy on saline conditions. As a preliminary study, we investigated the effect of microbial adaptation by an SBR operated with real $\mathrm{RO}$ concentrate obtained from water reuse pilot plant. Based on the preliminary study, we conducted a more quantitative experiment. Using parallel operation of MBRs, we evaluated the effect of the microbial adaptation strategy and developed a suitable adaptation strategy.

\section{Methods}

\subsection{Description of a pilot plant for water reclamation}

This study was carried out in the Yongyeon WWTP located in the Ulsan industrial complex in
Korea. Industrial wastewater and domestic wastewater were combined and treated. An advanced biological nutrient removal process is adapted and the total capacity is $250,000 \mathrm{~m}^{3} / \mathrm{d}$. The reuse pilot plant was designed based on the short-term field test [10]. The suitable treatment process for water reuse was determined as coagulation, ultrafiltration (UF), and RO processes. The pilot plant had the total treatment capacity of $72 \mathrm{~m}^{3} / \mathrm{d}$, and it was operated for 1 year. Specific operation conditions were applied as $16 \mathrm{mg} \mathrm{Al}_{2} \mathrm{O}_{3} / \mathrm{L}$ for coagulation, $1 \mathrm{~m} / \mathrm{d}$ for UF, and recovery of $75 \%$ for RO based on the previous study [10].

\subsection{Preliminary test on the effect of microbial adaptation for concentrate treatment}

As a preliminary test for microbial adaptation for saline wastewater, the $\mathrm{RO}$ concentrate from pilot plant was applied for SBRs inoculated by different activated sludges taken from different WWTPs. The volume of the reactor was $4 \mathrm{~L}$ and one cycle consisted of feeding (30 $\mathrm{min})$, aeration (180 $\mathrm{min})$, settling (15 $\mathrm{min})$, and decanting (15 min). The mixed liquor suspended solid (MLSS), hydraulic retention time (HRT), and solid retention time (SRT) were set as 3,000 $\mathrm{mg} / \mathrm{L}, 8 \mathrm{~h}$, and $30 \mathrm{~d}$, respectively, which were similar to the operation conditions of the WWTP.

To verify the effect of microbial adaptation, two SBRs (SBR 1 and 3) were inoculated with seeding sludge taken from the same WWTP (adapted sludge with high salinity and industrial wastewater, Yongyeon WWTP), and another (SBR 2) was inoculated by seeding sludge taken from a different WWTP that treats domestic wastewater only (unadapted sludge, Daejeon WWTP). Advanced nutrient removal processes are adapted to the both WWTPs. The influent TDS concentration showed significant difference depending on regional condition of WWTPs such as 3.17 and $0.46 \mathrm{~g} / \mathrm{L}$ for Yongyeon WWTP and Daejeon WWTP, respectively. Therefore, it was expected that the SBR 1 and 3 would have faster adaptation toward saline wastewater.

Moreover, SBRs were fed with different influent conditions to evaluate the possibility of sewer discharge of RO concentrate. One reactor (adapted sludge; SBR 3) was fed with raw wastewater only, and the others (SBR 1 and 2) were fed with a mixture of concentrate and raw wastewater based on a mass balance when the whole of the concentrate is assumed to be discharged to sewers. The scheme of reuse plant was designed to have $100,000 \mathrm{~m}^{3} / \mathrm{d}$ of reclaimed water production with $75 \%$ of recovery rate. Table 1 shows the characteristics of raw wastewater, concentrate, and the mixture of these fed to SBRs. 
Table 1

Influent characteristics of SBRs

\begin{tabular}{llll}
\hline & WWTP Influent (SBR 3) & Concentrate & Influent + concentrate (SBR 1 and 2) \\
\hline pH & 7.70 & 7.06 & 7.68 \\
SS $[\mathrm{mg} / \mathrm{L}]$ & 89.6 & - & 84.7 \\
$\mathrm{COD}_{\mathrm{Mn}}[\mathrm{mg} / \mathrm{L}]$ & 36.1 & 24.8 & 32.2 \\
$\mathrm{NH}_{4}^{+}-\mathrm{N}[\mathrm{mg} / \mathrm{L}]$ & 35.1 & 31.7 & 38.2 \\
$\mathrm{TDS}(\mathrm{g} / \mathrm{L})$ & 3.17 & 10.7 & 4.39 \\
\hline
\end{tabular}

\subsection{Development of a microbial adaptation strategy for saline wastewater by MBRs}

For the intensive study on the microbial adaptation strategy, lab-scale submerged MBRs (7 L) equipped with a hollow fiber membrane module (polypropylene, $0.1 \mathrm{~m}^{2}, 0.4 \mu \mathrm{m}$ ) were used. The activated sludge which was acclimated for $30 \mathrm{~d}$ with synthetic substrate was inoculated. The SRT and HRT were kept constant at $50 \mathrm{~d}$ and $18 \mathrm{~h}$ (corresponding to an operational flux of 3.5 LMH). Synthetic wastewater having a COD of 1,200 mg/L (C:N:P = 100:10:2) was supplied to the bioreactor. The detail characteristics of synthetic wastewater are presented in Table 2.

For adjustment of salt concentration, $\mathrm{NaCl}$ $(0-20 \mathrm{~g} / \mathrm{L})$ was introduced to the influent of the MBRs. Two types of adaptation strategies-instant shock and stepwise mode-were used to investigate the microbial adaptation during saline wastewater treatment. Removal efficiencies of DOC and ammonia were monitored to evaluate the overall performance, and microbial communities were compared through polymerase chain reaction-denaturing gradient gel electrophoresis (PCR-DGGE) analysis.

\subsection{Development of a microbial adaptation strategy for} saline wastewater by MBRs

COD, MLSS, and mixed liquor volatile suspended solid (MLVSS) were determined based on the APHA Standard Methods [11]. The DOC was determined by a TOC analyzer (Apollo 9000, Teledyne Tekmar, USA) after filtration of the samples with $0.45 \mu \mathrm{m}$ syringe filters. Ammonia was analyzed by titrimetric method after distillation with a distilling unit (KJELTEC 1026, FOSS, Denmark). The procedure for PCR-DGGE was described in a previous study [12].

\section{Results and discussion}

\subsection{Preliminary test on the effect of microbial adaptation} for concentrate treatment

In the preliminary test for investigating the effect of seeding sludge on $\mathrm{RO}$ concentrate treatment, reactor performances with different seeding sludges were compared. Fig. 1 shows the removal efficiency of DOC and ammonia. The result clearly shows that the SBR 1 had better performance than SBR 2. Ammonia

Table 2

Composition and concentration of synthetic wastewater for MBRs operation

\begin{tabular}{llll}
\hline Compound & Chemical formula & Molecular weight, g/mol & Concentration, mg/L \\
\hline $\begin{array}{l}\text { Organics and nutrients } \\
\text { Glucose }\end{array}$ & $\mathrm{C}_{6} \mathrm{H}_{12} \mathrm{O}_{6}$ & 180.0 & 1,120 \\
Ammonium sulfate & $\left(\mathrm{NH}_{4}\right)_{2} \mathrm{SO}_{4}$ & 132.1 & 568 \\
Potassium phosphate & $\mathrm{KH}_{2} \mathrm{PO}_{4}$ & 136.1 & 104 \\
Trace nutrients & & & 0.368 \\
Calcium chloride & $\mathrm{CaCl}_{2} 2 \mathrm{H}_{2} \mathrm{O}$ & 147.0 & 5.07 \\
Magnesium sulfate & $\mathrm{MgSO}_{4} 7 \mathrm{H}_{2} \mathrm{O}$ & 246.5 & 0.275 \\
Manganese chloride & $\mathrm{MnCl}_{2} 4 \mathrm{H}_{2} \mathrm{O}$ & 197.9 & 0.44 \\
Zinc sulfate & $\mathrm{ZnSO}_{4} 7 \mathrm{H}_{2} \mathrm{O}$ & 287.5 & 1.45 \\
Ferric chloride anhydrous & $\mathrm{FeCl}_{3}$ & 162.2 & 0.391 \\
Cupric sulfate & $\mathrm{CuSO}_{4} 5 \mathrm{H}_{2} \mathrm{O}$ & 249.7 & 0.42 \\
Cobalt chloride & $\mathrm{CoCl}_{2} 6 \mathrm{H}_{2} \mathrm{O}$ & 237.9 & 1.26 \\
Sodium molybdatedihydrate & $\mathrm{Na}_{2} \mathrm{MoO}_{4} 2 \mathrm{H}_{2} \mathrm{O}$ & 242.0 & 30 \\
Yeast extract & & & \\
\hline
\end{tabular}



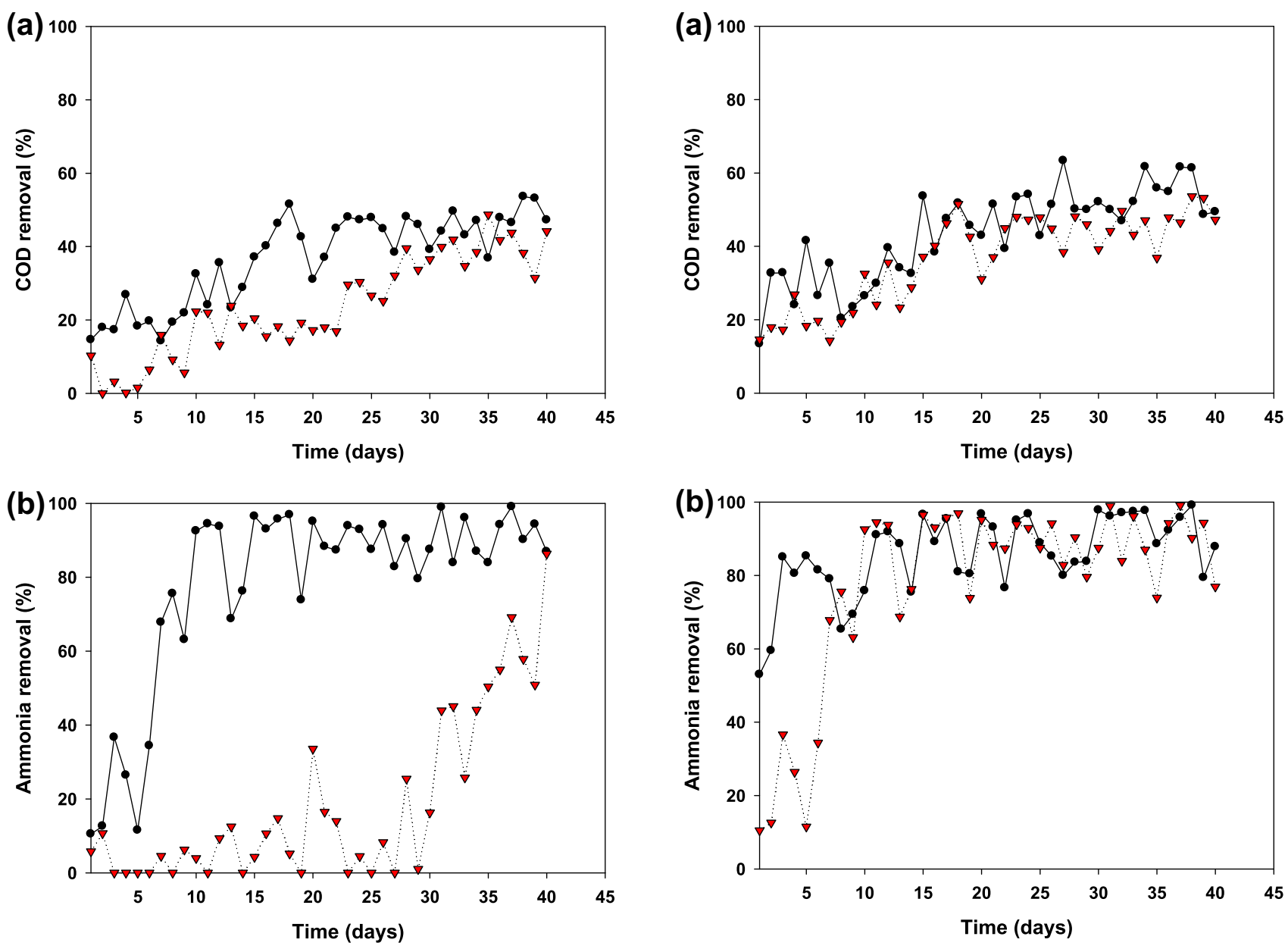

Fig. 1. Effect of seeding sludge on SBR performance ((a) COD removal, (b) ammonia). Circle: SBR 1 (adapted), triangle: SBR 2 (unadapted).

removal efficiency was significantly inhibited by saline wastewater for unadapted seeding sludge.

The removal efficiency of COD and ammonia gradually increased with operation time. After one month of operation, the removal efficiency started to increase and it reached a performance similar to SBR 1 . The increase of removal efficiency directly showed the adaptation of sludge in the reactor for certain wastewater. $\mathrm{Li}$ et al. [13] also reported that an adapted mixed culture had a huge potential for biodegradation of various contaminants in industrial wastewater.

Additionally, a mixture of $\mathrm{RO}$ concentrate and wastewater was applied to the same seeding sludge (adapted) to verify the possibility of real application (SBR 3). Fig. 2 shows the COD and ammonia removal efficiency according to different mixing ratios between wastewater and concentrate. Both COD and ammonia removal were initially inhibited by higher salt concen-

Fig. 2. Effect of salt concentration on SBRs performance ((a) DOC removal, (b) ammonia). Circle: SBR 3 (concentrate + raw wastewater), triangle: SBR 2 (raw wastewater only).

tration in the mixture but recovered in a week (SBR 2). Then, the removal efficiency was stable during $40 \mathrm{~d}$ of operation. This clearly showed possibility to apply concentrate to a WWTP without any significant adverse effect if an adequate adaptation time and strategy are allowed.

Based on this finding, we hypothesized that the effect of high salt concentration on wastewater treatment is dependent on the microbial adaptation. For a more intensive and quantitative study on microbial adaptation strategies under saline conditions, lab-scale MBRs were used.

\subsection{Development of a microbial adaptation strategy for saline wastewater by a MBR}

The variations of DOC and ammonia concentrations in the MBR's effluent were continuously 

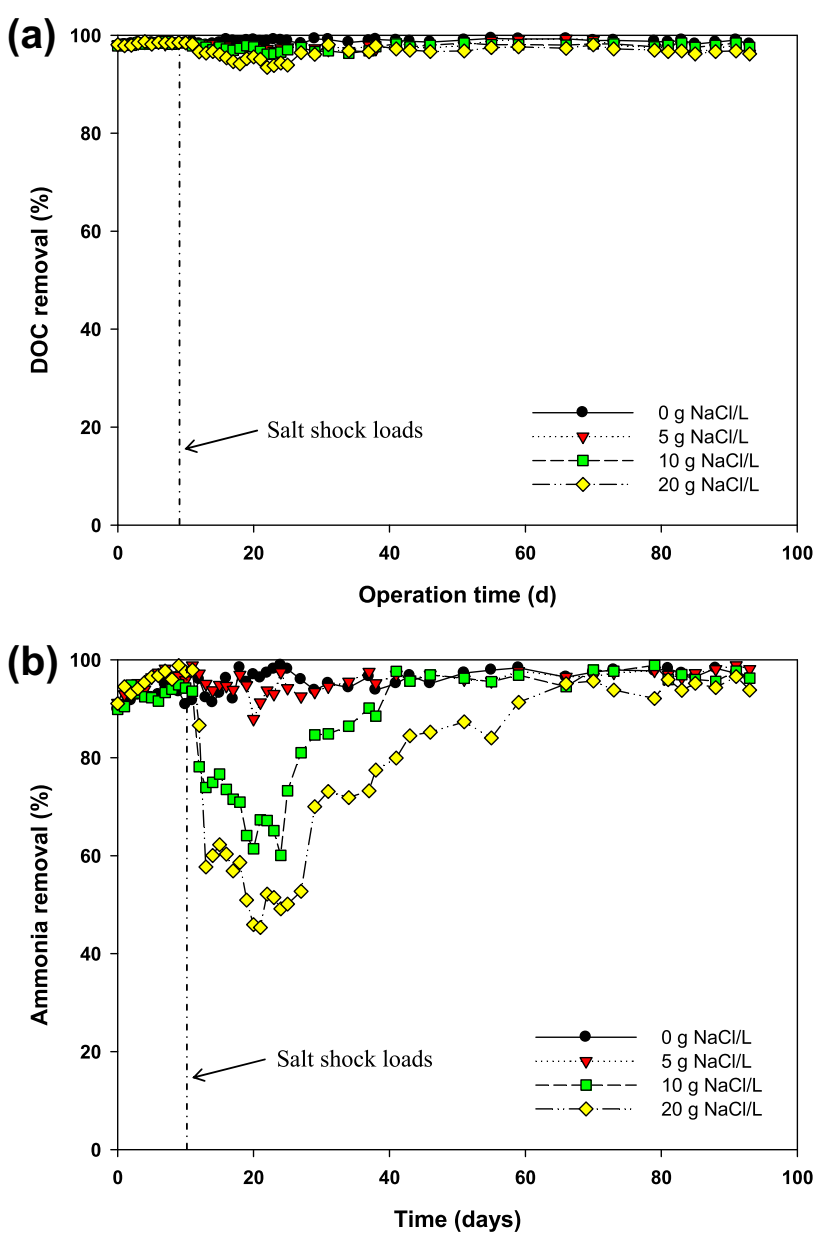

Fig. 3. Effect of instant salt shock on MBR performance ((a) DOC removal and (b) ammonia removal).

monitored to investigate the effect of salt concentration on MBR performance with different adaptation strategies. An increase in salt concentration did not significantly change the DOC removal efficiencies in any of the cases (> 95\%) (Fig. 3(a)). The high biomass concentrations in the MBRs may make it possible to withstand shock salt loads. In addition, the membrane would act as a barrier that prevents the washout of solids and dead biomass that could contribute to an increase in organics in the effluent [14].

On the other hand, salinity exhibited a significant negative impact on the nitrification process (Fig. 3(b)). In the case of instant salt shock, ammonia removal efficiency decreased from 95 to $46 \%$ as the salt concentration increased from 0 to $20 \mathrm{~g} \mathrm{NaCl} / \mathrm{L}$ (Table 3). According to Moussa et al. [15], ammonia oxidizers are more sensitive to salt stress than heterotrophs removing organic matter. That indicated that freshwater nitrifiers are very sensitive to high salinity, and once they are affected or washed out, considerable

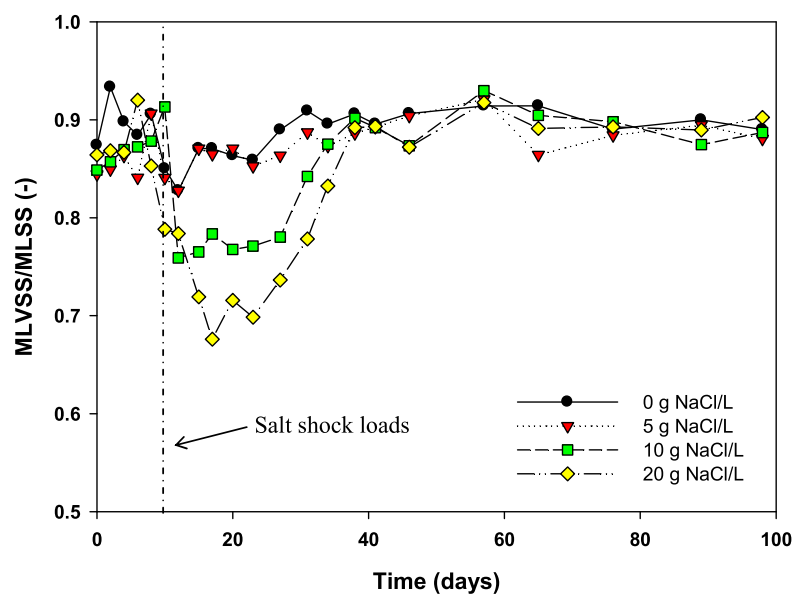

Fig. 4. Change of MLVSS/MLSS ratio during instant salt shock.

time will be required to reestablish them due to their slow growth rates. Therefore, the longer recovery period for ammonia removal than that of organic removal could be caused by a high sensitivity of ammonia oxidizer to salinity.

The removal efficiency of ammonia was recovered after $20-25 \mathrm{~d}$ of operation by adaptation. The removal efficiency gradually increased and reached to stable

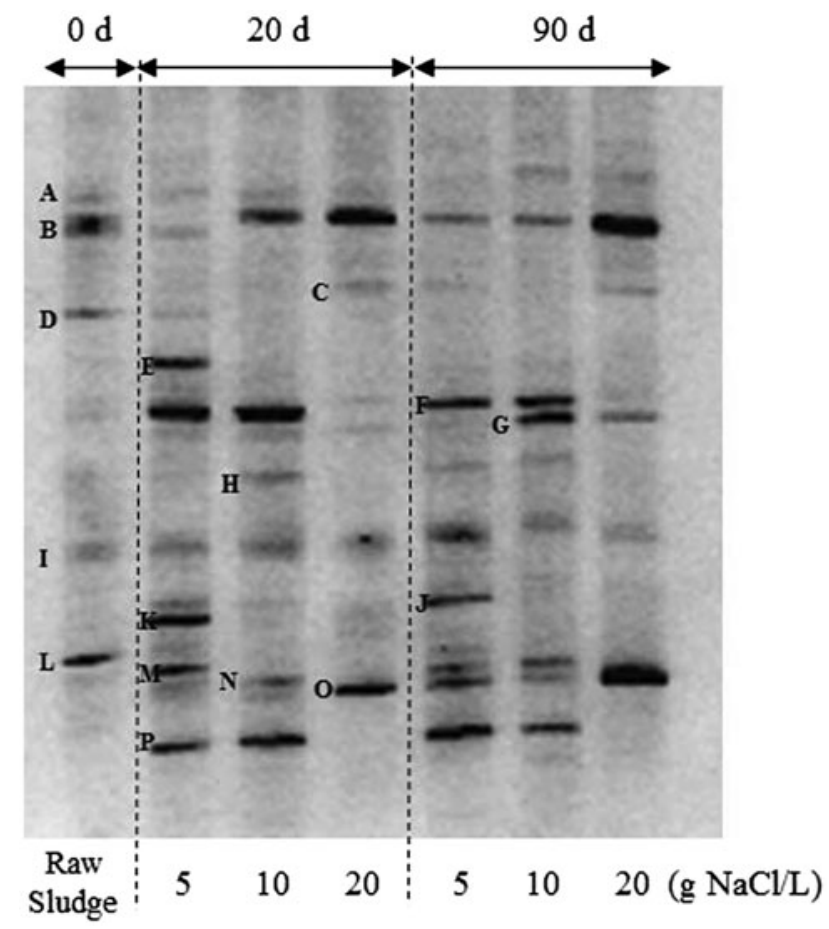

Fig. 5. DGGE gel banding profiles of microbial communities in the MBRs at different salt concentrations. 
Table 3

Ammonia removal and recovery periods for various $\mathrm{NaCl}$ concentrations

\begin{tabular}{lll}
\hline $\begin{array}{l}\text { Salt contents } \\
(\mathrm{g} / \mathrm{L})\end{array}$ & $\begin{array}{l}\text { Minimum efficiency } \\
(\%)\end{array}$ & $\begin{array}{l}\text { Recovery periods } \\
(\mathrm{d})\end{array}$ \\
\hline 0 & 95 & - \\
5 & 87 & 11 \\
10 & 61 & 30 \\
20 & 46 & 56 \\
\hline
\end{tabular}

condition similar with the condition before salt shock. Fig. 4 presents decrease of the MLVSS/MLSS ratio after instant salt shock loads. The MLVSS/MLSS ratio in an MBR serves as an important indication of the amount of viable microbial sludge in the total sludge. The ratio recovered in a way similar, but little faster than the recovery of actual ammonia removal efficiency. This result once again reveals sensitivity of nitrifier under salt shock. The similar recovery pattern of MLVSS/MLSS ratio and ammonia removal efficiency is explaining that the recovery of ammonia removal efficiency after a certain recovery time is closely related to the microbial community that could adapt itself to the increasing salt concentration, which would result in the death of biomass $[8,16]$.

The microbial communities were compared through a PCR-DGGE. DGGE gel band profiles in the MBRs at different instant salt shock loads are illustrated in Fig. 5 and Table 4. Microbial diversity decreased at higher salt concentrations. Bands D, E, F, $\mathrm{K}$, L, and $\mathrm{P}$ completely disappeared at 10 and $20 \mathrm{~g}$ $\mathrm{NaCl} / \mathrm{L}$. However, bands A, B, G, I, and $\mathrm{N}$

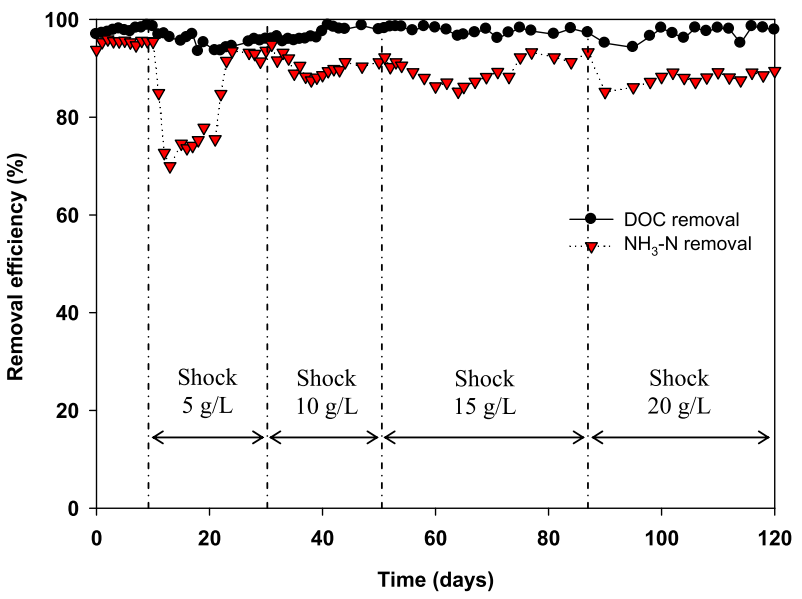

Fig. 6. Reactor performances in various $\mathrm{NaCl}$ concentrations (stepwise shock mode).

(Nitrosomonas eutropha and Nitrosomonas europaea) were still present at $20 \mathrm{~g} / \mathrm{L}$ of salt and the intensity of bands $\mathrm{E}$ and $\mathrm{N}$ especially increased with salt concentration increments. These findings support the recovery of ammonia removal efficiency after certain recovery periods.

From this finding, it was clear that the microbial adaptation was essential for stable operation for saline wastewater treatment. To verify and develop a proper adaptation strategy, the salt concentration was gradually increased after the reactor performance was recovered and stabilized. As shown in Fig. 6, the stepwise mode showed stable DOC and ammonia removal performance compared with instant shock loads. It was found that, with an adequate acclimation period and

Table 4

DDGE fragments of micro-organisms by $16 \mathrm{~S}$ rDNA

\begin{tabular}{lll}
\hline DGGE bands & Closest identity & Accession number \\
\hline A & Nitrosomonas europaea (ATCC 25978) & GQ451713 \\
B & Nitrosomonas europaea (ATCC 25978) & GQ451713 \\
C & Methyloversatilis universalis (FAM 5) & DQ442273 \\
D & Azohydromonas lata (IAM 12599) & AB188125 \\
E & Azohydromonas lata (IAM 12599) & AB188125 \\
F & Dechloromonas agitata (CKB) & AF170357 \\
G & Nitrosomonas europaea (ATCC 25978) & GQ451713 \\
H & Burkholderia megapolitana (LMG 23650) & AM489502 \\
I & Nitrosomonas europaea (ATCC 25978) & GQ451713 \\
J & Methyloversatilis universalis (FAM 5) & DQ442273 \\
K & Nitrosomonas europaea (ATCC 25978) & GQ451713 \\
L & Shewanella japonica (KMM 3299) & KMM 3299T \\
M & Schlegelella thermodepolymerans (K 14) & AY152824 \\
N & Nitrosomonas europaea (ATCC 25978) & GQ451713 \\
O & Nitrosomonas europaea (ATCC 25978) & GQ451713 \\
P & Nitrosomonas eutropha (C 91) & Q0AG70 \\
\hline
\end{tabular}


incrementally increased salt content, activated sludge could be adapted to high-saline conditions $(<20 \mathrm{~g} / \mathrm{L})$. Therefore, the sewer discharge of concentrate with a proper adaptation strategy could be considered as an applicable technology.

\section{Conclusion}

In this study, the microbial adaptation strategy for saline wastewater treatment including concentrate from water reuse was investigated. Sewer discharge is one of the most common methods for concentrate disposal, but this way could have a negative impact on biological treatment systems due to high salinity. The feasibility of application of sewer discharge was evaluated with different seeding sludges and mixing ratios between the concentrate and raw wastewater. The results clearly showed that the reactor performance was inhibited by higher salinity but it could be recovered by operation time to allow microbial adaptation.

For a more intensive and quantitative study on adaptation strategy, lab-scale MBRs were used. With the instant shock load, ammonia removal decreased with an increasing salt concentration $(0-20 \mathrm{~g} / \mathrm{L})$, but it recovered after adaptation periods (30-40 d). The PCR-DGGE results indicated that nitrifiers were still present in high salinity. Moreover, the inhibition effect could be minimized by a gradual increase in salt concentration. Therefore, a step wise or gradual increase adaptation strategy should be considered prior to sewer discharge of RO concentrate without significant inhibition of the biological wastewater treatment process.

\section{Acknowledgments}

This work was financially supported by the National Research Foundation of Korea (NRF) grant funded by the Korea government Ministry of Education, Science and Technology (MEST) (NRF2012M1A2A2026587) and Korea Ministry of Environment (MOE) as Public technology program based on Environmental Policy Program.

\section{References}

[1] G. Mauguin, P. Corsin, Concentrate and other waste disposals from SWRO plants: Characterization and reduction of their environmental impact, Desalination 182 (2005) 355-364.
[2] A. Pérez-González, A.M. Urtiaga, R. Ibáñez, I. Ortiz, State of the art and review on the treatment technologies of water reverse osmosis concentrates, Water Res. 46 (2012) 267-283.

[3] M.C. Mickley, Membrane Concentrate Disposal: Practices and Regulation, second ed., The U.S. Dept. of Interior, Bureau of Reclamation, Denver, CO, 2004.

[4] E.R. Rene, S.J. Kim, H.S. Park, Effect of COD/N ratio and salinity on the performance of sequencing batch reactors, Bioresour. Technol. 99 (2008) 839-846.

[5] A. Uygur, F. Karg1, Salt inhibition on biological nutrient removal from saline wastewater in a sequencing batch reactor, Enzyme Microb. Technol. 34 (2004) 313-318.

[6] C.C. Hong, S.K. Chan, H. Shim, Effect of chloride on biological nutrient from wastewater, J. Appl. Sci. Environ. Sanit. 2 (2007) 85-92.

[7] H.Y. Ng, S.L. Ong, W.J. Ng, Effects of sodium chloride on the performance of a sequencing batch reactor, J. Environ. Eng. 131 (2005) 1557-1564.

[8] K.N. Yogalakshmi, K. Joseph, Effect of transient sodium chloride shock loads on the performance of submerged membrane bioreactor, Bioresource Technol. 101 (2010) 7065-7072.

[9] K. Shi, W. Zhou, H. Zhao, Y. Zhang, Performance of halophilic marine bacteria inocula on nutrient removal from hypersaline wastewater in an intermittently aerated biological filter, Bioresour. Technol. 113 (2012) 280-287.

[10] Y.H. Hwang, C.M. Moon, Y.T. Ahn, S. Kim, J.L. Lim, H.S. Shin, Selection of pretreatment process and reverse osmosis membrane for a wastewater reclamation system for the industrial water use, Desalin. Water Treat. 51 (2013) 5466-5474.

[11] Standard Methods for the Examination of Water and Watewater, twenty first ed., Ametican Public Health Association/American Water Works Association/ Water Environment Federation, Washington, DC, 2005.

[12] D. Jang, Y. Hwang, H. Shin, W. Lee, Effects of salinity on the characteristics of biomass and membrane fouling in membrane bioreactors, Bioresour. Technol. 141 (2013) 50-56.

[13] T. Li, J. Liu, R. Bai, D.G. Ohandja, F.S. Wong, Biodegradation of organonitriles by adapted activated sludge consortium with acetonitrile-degrading microorganisms, Water Res. 41 (2007) 3465-3473.

[14] A.B. Deorsola, G.C. Camarinha, D.D. Carvalho, G.L. Sant'Anna, Biological treatment of saline wastewaters in an aerobic sequencing batch reactor, Environ. Prog. Sustainable Energy 32 (2013) 198-205.

[15] M.S. Moussa, D.U. Sumanasekera, S.H. Ibrahim, H.J. Lubberding, C.M. Hooijmans, H.J. Gijzen, M.C. van Loosdrecht, Long term effects of salt on activity, population structure and floc characteristics in enriched bacterial cultures of nitrifiers, Water Res. 40 (2006) 1377-1388.

[16] O. Lefebvre, R. Moletta, Treatment of organic pollution in industrial saline wastewater: A literature review, Water Res. 40 (2006) 3671-3682. 